\title{
Are foods naturally rich in glutamic acid an alternative to sodium reduction?
}

\author{
Fernanda Ferreira dos SANTOS ${ }^{1 *}$ (D), Natalie Marinho DANTAS ${ }^{1}$, Natália Koren SIMONI ${ }^{1}$, \\ Laura Stonoga PONTES ${ }^{1}$, Maria Elisabeth Machado PINTO-e-SILVA ${ }^{1}$
}

\begin{abstract}
Chronic non-communicable diseases (NCDs) prevalence has been growing, hence the importance of studying food alternatives with reduced sodium content sensory well accepted. Develop culinary preparations reduced in sodium, with addition of glutamic acid-rich ingredients, and evaluate their sensory acceptance. Research about use of glutamic acid-rich ingredients in recipes was done. Recipes were developed, aiming good sensory acceptance; their salt content was estimated by using TACO and USDA's food composition table. They were later submitted to sensory analysis, in which was applied 9-point hedonic scale (global acceptance and flavor), and linear scale of $10 \mathrm{~cm}$ (salt intensity). Data was analyzed by ANOVA and Tukey Test $(\mathrm{p}<0.05)$ with software FIZZ Biosystemes. Herbs pie samples with parmesan cheese had better acceptance and salt intensity was perceived as moderate. Bruschetta samples, with tomatoes, were well accepted regardless the presence of refined salt or herbs; and had a harmonious salt intensity perception. Salt intensity was considered adequate on chicken stroganoff samples while champignon mushrooms provided better global acceptance. All samples had 50-60\% less salt than traditional recipes. Ingredients naturally rich in glutamic acid (parmesan cheese, tomatoes and mushrooms) are good for strategies of sodium content reduction in culinary preparations, without reduce sensorial acceptance.
\end{abstract}

Keywords: glutamic acid; sodium reduction; food composition; public health; taste perception.

Practical Application: With the perpetuation of nutritional transition, food choice has been influenced by the environment where individuals live. Furthermore, the prevalence of chronic non-communicable diseases related to cardiovascular comorbidities has been growing, making indispensable the development of studies about food alternatives with reduced sodium content without reducing good sensorial acceptance. This strategy may help improve patients' adherence to nutritional treatment.

\section{Introduction}

With advances in globalization and nutritional transition, people from different socioeconomic backgrounds have been exposed to a constantly changing environment, which influences their food choices (Popkin et al., 2012; Popkin, 2015). As a result, the population is increasingly exposed to a large amount of sodium content in food due to the industrialization process (Kramer, 2017), and table salt indiscriminate addition during preparation and consumption, as it represents around $74,4 \%$ of household sodium availability (Sarno et al., 2013).

Excessive consumption of this mineral contributes to the increase of chronic non-communicable diseases (NCDs) prevalence (Neves et al., 2017) as well as the Brazilian Unified Health System's outlay (SUS). As a matter of fact, in 2015 cardiovascular diseases were responsible for the direction of 37,1 billion Reais of monetary resources destined for SUS, 17\% higher than the value destined for the same purpose in 2010 (Siqueira et al., 2017), suggesting a tendency to increase costs in the coming years (Asaria et al., 2007; Cobiac et al., 2010; Gaitán et al., 2015; Kassebaum et al., 2016; Sociedade Brasileira de Cardiologia, 2007, 2016; Wang \& Labarthe, 2011).

One of the primary actions taken to reverse this scenario relies on stimuli to restrict the daily sodium ingestion to levels lower than those established by World Health Organization as borderline (Webster et al., 2014; World Health Organization, 2006; Trieu et al., 2015). Nonetheless, it is known that Brazilian population daily ingests around two times the recommended content (Sarno et al., 2009, 2013); what makes abrupt restriction difficult to maintain in the long-term.

When made without professional accompaniment or adequate counselling, sodium restriction leads to contradict the guidelines advocated by Health Ministry, presented in the Dietary Guidelines for the Brazilian Population, which exposes the importance of sharing a meal with special people (Brasil, 2014). In parallel it is known that food choices are extremely complex, permeated by social questions and emotions (Mattes \& Vickers, 2018; Moreira, 2010), and that therefore, it must be considered and respected in dietary prescriptions that aim to modify longstanding alimentary habits and adhesion to nutritional treatment.

Studies about low-salt preparations acceptance can guide food services and food producers about the amount of salt to be used (Oliveira et al., 2018). Chefs who understand umami taste realized that umami keeps the palatability of dishes even though the concentration of salt is lower than usual (Ninomiya, 2015). Many studies aims a greater adherence to treatments and nutritional counselling programs (Guimarães et al., 2010; Souza 
\& Silvestre, 2013; Zanetti et al., 2015). However, few studies analyze culinary preparations reduced in sodium content and use of ingredients naturally rich in glutamic acid with this objective (Dermiki et al., 2013; Galvão et al., 2014, Hoppu et al., 2017). Moreover, just a few of them approach the use of these foods to stimulate the reduction of sodium consumption (Ghawi et al. 2014; Myrdal Miller et al., 2014; Guinard et al., 2016); making this work important for the public and the supplementary health, at national level.

Food naturally rich in glutamic acid such as meats, vegetables and dairy products (Amaya-Farfan \& Airoldi, 2011; Drake et al., 2007; Ganesan et al., 2014), highlight food which they are associated, by salt formation from the interaction of glutamic acid and sodium molecules in the presence of neutral $\mathrm{pH}$; reducing the need of salt (refined, Himalayan, etc) during preparation and consumption (Silveira \& López, 2011; Zhang et al., 2013; Kurihara, 2015; Chew et al., 2017; Nishimura et al., 2016).

In this context, the aim of the present study was to develop preparations reduced in sodium with sensorial characteristics highlighted through the use of ingredients naturally rich in glutamic acid.

\section{Materials and methods}

\subsection{Selection of ingredients and culinary recipes}

Ingredients naturally rich in glutamic acid, such as parmesan cheese, tomato and champignon mushroom, were selected for presenting respectively $1680 \mathrm{mg} / 100 \mathrm{~g}, 246 \mathrm{mg} / 100 \mathrm{~g}$ and $42 \mathrm{mg} / 100 \mathrm{~g}$ of the compound of interest (Yamaguchi \& Ninomiya, 2000); and for being widely consumed among Brazilians, specially tomato and cheese (Souza et al., 2013).

Traditional recipes which have these ingredients in their composition were selected: herbs pie containing parmesan cheese; bruschetta, with tomato; and chicken stroganoff with champignon mushroom.

\subsection{Pilot test}

During pilot test were evaluated six different samples for each recipe, with variation on table salt, ingredients naturally rich in glutamic acid and aromatic herbs (dehydrated basil, parsley and oregano) content. Samples sensorially harmonic, resembling the original recipe with regards to sensorial characteristics, were selected (four samples of herbs pie, three samples of bruschetta and three samples of chicken stroganoff). Samples excluded during pilot test had sensory characteristics similar to those that were selected.

Samples selected from the pilot test had base ingredients presented in equivalent quantities, varying the use of refined salt, aromatic herbs and ingredients naturally rich in glutamic acid (Table 1), aiming to identify which of them had higher influence on acceptance.

\subsection{Estimative of sodium in samples}

Samples considered sensorially adequate had its sodium content measured and compared with the traditional recipe. To do so, the Brazilian Table of Food Composition (Universidade Estadual de Campinas, 2011) was used and USDA Food Composition Database when data was missing in the former (United States Department of Agriculture, 2015).

\subsection{Sensory analysis}

Sensory analyses were performed during the morning of three different days of June 2017 (one session for each recipe), in an illuminated room with white light and individual booths equipped with computers that used the software FIZZ Biosystemes (version 2.05). Coded samples were presented randomly, in complete blocks, in individual trays with napkin, cutlery, a glass of water and salted biscuit to neutralize flavor. Judges were untrained adults, who did not have health conditions that could influence or preclude their evaluation.

A group of 60 judges participated in the analysis of the herbs pie, while 50 judges evaluated samples of bruschetta, and 46 judges evaluated samples of chicken stroganoff. Sample size was determine based on Stone et al. (2012) who present the possibility to work with 25 and 50 assessors up to 75 , being possible to establish a statistically significant difference with 45 judges.

In each session it was applied the affective test of acceptability with the use of the hedonic scale of 9-points to evaluate global acceptance and flavor (1- I greatly disliked/9- I greatly liked) (Dutcosky, 2013a; Stone \& Sidel, 2004). And was applied the linear

Table 1. Sample content of herbs pie, bruschetta and chicken stroganoff.

\begin{tabular}{llccccc}
\hline & $\begin{array}{c}\text { Refined Salt } \\
(\%)\end{array}$ & $\begin{array}{c}\text { Aromatic Herbs } \\
(\%)\end{array}$ & $\begin{array}{c}\text { Parmesan Cheese } \\
(\%)\end{array}$ & $\begin{array}{c}\text { Tomato } \\
(\%)\end{array}$ & $\begin{array}{c}\text { Champignon } \\
\text { Mushroom (\%) }\end{array}$ \\
\hline Herbs Pie & Sample "1" & 0.0 & 0.2 & 0.0 & 0.0 & 0.0 \\
& Sample "2" & 0.0 & 0.2 & 1.9 & 0.0 & 0.0 \\
& Sample "3" & 0.6 & 0.2 & 0.0 & 0.0 & 0.0 \\
\multirow{5}{*}{ Bruschetta } & Sample "4" & 0.6 & 0.2 & 1.9 & 0.0 & 0.0 \\
& Sample "1" & 0.0 & 0.0 & 0.0 & 15.9 & 0.0 \\
& Sample "2" & 0.2 & 0.6 & 0.0 & 15.8 & 0.0 \\
Chicken Stroganoff & Sample "3" & 0.0 & 0.6 & 0.0 & 15.8 & 0.0 \\
& Sample "1" & 0.1 & 0.0 & 0.0 & 0.0 & 5.7 \\
& Sample "2" & 0.0 & 0.4 & 0.0 & 0.0 & 5.7 \\
& Sample "3" & 0.3 & 0.5 & 0.0 & 0.0 & 0.0 \\
\hline
\end{tabular}


scale of $10 \mathrm{~cm}$ to evaluate salt intensity ( 0 - not salty/10-very salty) (Dutcosky, 2013b; Stone \& Sidel, 2004).

The present study has been approved by Research Ethics Committee of School of Public Health from University of São Paulo, and all judges signed an Informed Consent Form before receiving the samples (resolution 67777616.3.0000.5421, June 23 ${ }^{\text {rd }}$, 2017, Brazilian National Health Council).

\subsection{Statistical analysis}

In order to verify the sensory acceptance of preparations, it was applied a variance analysis (two-way ANOVA) and a mean comparison test (Test Tukey) using $\mathrm{p}<0.05$ significance, performed with FIZZ Biosystemes (version 2.05).

\section{Results}

\subsection{Estimative of sodium in samples}

According to the data obtained from the sodium content estimative, was observed that herb pies and chicken stroganoff's samples had less than $50 \%$ of traditional recipe's salt content, assuming that the traditional one had $100 \%$ of salt content (Figure 1). While bruschetta's sample had less than $60 \%$ of traditional recipe salt content. All of them were percentually well received over salt intensity perception (Figure 1).

\subsection{Herbs pie}

Flavor acceptance test results in a statistically significant difference amongst herbs pies with regards to flavor and global acceptance; whereas samples with refined salt (sample " 3 " and sample " 4 ") were better accepted, in a statistically and percentually significant way, considering a score equal or higher than six in the 9-points hedonic scale. At the same time, samples that had parmesan cheese (sample "2" and sample " 4 ") were percentually better accepted than those that did not had it (Table 2).

Regarding to salt intensity, there was no statistically significant difference between samples, regardless of the presence or absence of refined salt and parmesan cheese (Table 2).

\subsection{Bruschetta}

Data evaluation from sensory analysis of bruschetta's samples (Table 3) points out that regardless of refined salt and aromatic herbs presence, all samples were well received by judges. As a matter of fact, percentages of global and flavor acceptance were similar among judges, once there was a percentage prevalence of participants who indicated acceptance equal or superior to category "6- I slightly liked".

Evaluating salt perception, it was noticed that the mean score was lower than five, that is, intermediate perceived salt intensity, without statistically significant difference between samples. Yet, percentually, it was noticed considerable concentration between score four and six from the linear scale of $10 \mathrm{~cm}$, especially on sample " 3 ".

\subsection{Chicken stroganoff}

Values obtained over acceptance tests showed that there was statistically significant difference between chicken stroganoff samples with regards to global acceptance, in which sample "1" received higher approval mean (Table 4)
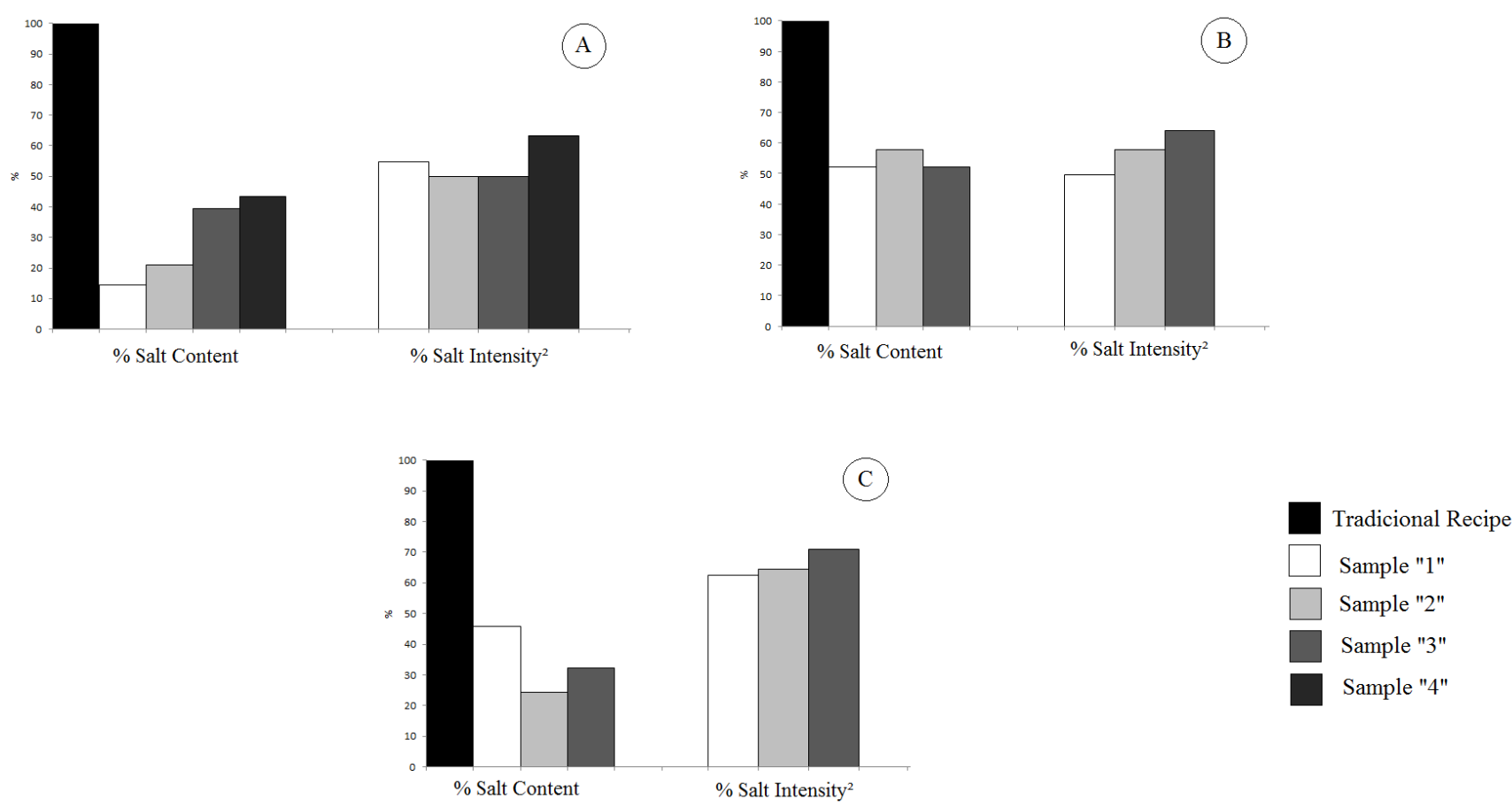

Figure 1. Percentage of sodium content and salt intensity (4-6 points) observed in traditional recipe and test samples from herbs pie (A), bruschetta (B) and chicken stroganoff (C). 
Table 2. Means and standard deviation of flavor and global acceptance attributes and salt intensity perception of herbs pie samples.

\begin{tabular}{|c|c|c|c|c|c|c|}
\hline \multirow[b]{2}{*}{ Samples } & \multicolumn{2}{|c|}{${ }^{1}$ Favor } & \multicolumn{2}{|c|}{${ }^{1}$ Global Acceptance } & \multicolumn{2}{|c|}{${ }^{2}$ Salt Intensity } \\
\hline & Mean/SD & Acceptance $\geq 6(\%)$ & Mean/SD & Acceptance $\geq 6(\%)$ & Mean/SD & $\begin{array}{l}\text { Equilibrium } \\
\text { (4-6 Points) }\end{array}$ \\
\hline Sample "1" & $4.38(2.06) c^{*}$ & 36.7 & $4.60(2.16) c^{\star}$ & 36.7 & $3.60(2.05) \mathrm{a}^{*}$ & 55.0 \\
\hline Sample " 3 " & $6.43(1.74) \mathrm{a}^{\star}$ & 71.6 & $6.50(1.62) \mathrm{a}^{\star}$ & 68.3 & $3.20(2.16) \mathrm{a}^{\star}$ & 50.0 \\
\hline Sample "4" & $6.52(1.50) \mathrm{a}^{\star}$ & 81.7 & $6.58(1.51) \mathrm{a}^{\star}$ & 83.3 & $3.57(2.07) \mathrm{a}^{\star}$ & 63.3 \\
\hline
\end{tabular}

${ }^{1} \%$ Affective Acceptance Test ( $\geq 6-9$ points in the hedonic scale); ${ }^{2} \%$ Salt intensity equilibrium perception $\left(4-6\right.$ points in a $10 \mathrm{~cm}$ scale); ${ }^{\star}$ Means followed by equal letters in the same column, does not show statistically significant difference $(\mathrm{p}<0.05)$ according to Teste Tukey; SD: standard deviation.

Table 3. Means and standard deviation of flavor and global acceptance attributes and salt intensity perception of bruschetta.

\begin{tabular}{|c|c|c|c|c|c|c|}
\hline \multirow[b]{2}{*}{ Samples } & \multicolumn{2}{|c|}{${ }^{1}$ Favor } & \multicolumn{2}{|c|}{${ }^{1}$ Global Acceptance } & \multicolumn{2}{|c|}{${ }^{2}$ Salt Intensity } \\
\hline & Mean/SD & Acceptance $\geq 6(\%)$ & Mean/SD & Acceptance $\geq 6(\%)$ & Mean/SD & $\begin{array}{l}\text { Equilibrium } \\
\text { (4-6 Points) }\end{array}$ \\
\hline Sample "1" & $6.52(1.64) \mathrm{a}^{\star}$ & 78.0 & $6.64(1.55) \mathrm{a}^{*}$ & 88.0 & $3.00(2.00) \mathrm{a}^{*}$ & 48.0 \\
\hline Sample “2” & $6.84(1.48) \mathrm{a}^{*}$ & 80.0 & $7.04(1.41) \mathrm{a}^{*}$ & 88.0 & $3.01(2.01) \mathrm{a}^{*}$ & 56.0 \\
\hline Sample "3" & $6.54(1.59) \mathrm{a}^{*}$ & 80.0 & $6.72(1.40) \mathrm{a}^{*}$ & 86.0 & $3.22(1.79) \mathrm{a}^{*}$ & 62.0 \\
\hline
\end{tabular}

${ }^{1} \%$ Affective Acceptance Test ( $\geq 6-9$ points in the hedonic scale); ${ }^{2} \%$ Salt intensity equilibrium perception $\left(4-6\right.$ points in a $10 \mathrm{~cm}$ scale); ${ }^{*}$ Means followed by equal letters in the same column, does not show statistically significant difference $(\mathrm{p}<0.05)$ according to Teste Tukey; SD: standard deviation.

Table 4. Means and standard deviation of flavor and global acceptance attributes and salt intensity perception of chicken stroganoff.

\begin{tabular}{|c|c|c|c|c|c|c|}
\hline \multirow[b]{2}{*}{ Samples } & \multicolumn{2}{|c|}{${ }^{1}$ Favor } & \multicolumn{2}{|c|}{${ }^{1}$ Global Acceptance } & \multicolumn{2}{|c|}{${ }^{2}$ Salt Intensity } \\
\hline & Mean/SD & Acceptance $\geq 6(\%)$ & Mean/SD & Acceptance $\geq 6$ (\%) & Mean/SD & $\begin{array}{l}\text { Equilibrium } \\
\text { (4-6 Points) }\end{array}$ \\
\hline Sample "1" & $6.78(1.51) \mathrm{a}^{\star}$ & 71.7 & $6.96(1.43) \mathrm{a}^{\star}$ & 82.6 & $3.55(1.70) \mathrm{a}^{*}$ & 63.0 \\
\hline Sample "3" & $6.37(1.48) \mathrm{a}^{*}$ & 80.4 & $6.37(1.54) b^{*}$ & 71.7 & $3.95(2.10) \mathrm{a}^{*}$ & 71.7 \\
\hline
\end{tabular}

${ }^{1} \%$ Affective Acceptance Test ( $\geq 6$-9 point in the hedonic scale); ${ }^{2} \%$ Salt intensity equilibrium perception (4-6 points in a $10 \mathrm{~cm}$ scale); ${ }^{*}$ Means followed by equal letters in the same column, does not show statistically significant difference $(\mathrm{p}<0.05)$ according to Teste Tukey; SD: standard deviation.

On the other hand, flavor and salt intensity attributes did not result in statistically significant difference, once flavor acceptance was considered good (mean score varied between "6- I slightly liked" and "7- I moderately liked" in the 9-points hedonic scale), and salt perception was considered intermediary; in which sample " 3 " had salt perception closer to the balance. Briefly, there was percentage predominance of good acceptance for all attributes assessed (Table 4).

\section{Discussion}

This study evaluated three culinary preparations: herbs pie, bruschetta and chicken stroganoff, with different combinations of naturally rich glutamic acid ingredients, reduction in refined salt content and its influence over consumer's acceptance and salt intensity perception.

Sensory analysis of different samples from the three culinary preparations over flavor, global acceptance and salt intensity demonstrated that the initial hypothesis, that the presence of ingredients vehicles of glutamic acid would contribute for better preparations acceptance, proved to be true.

As for the flavor attribute, it was observed that herbs pie's samples that had parmesan cheese, naturally rich in glutamic acid, were better accepted than those without it; and that the presence of parmesan cheese collaborated with the preparation's sensorial balance, even when using less than $50 \%$ of traditional recipe's salt content.

Evaluating bruschetta's sample made possible to observe that even with less than $60 \%$ of traditional recipe's salt content, presence or absence of refined salt and aromatic herbs, all samples were well accepted; what suggests that the presence of tomato, per se, naturally rich in glutamic acid favored the good acceptance of all samples.

Ghawi et al. (2014) observed in a study that evaluated tomato soup acceptance reduced in salt content and increased with spices, from repeated exposures, that salt reduction led to an immediate decline on judges' acceptance, and the presence of spices was not able to balance this decline. However, it was also observed that the use of spices was capable of improving the salt perception and compensating around $53.0 \%$ of the mineral reduction. In the case of bruschetta's acceptance, the salt reduction did not reduce significantly the samples' acceptance.

Good approval of analyzed attributes related to chicken stroganoff was detected, even though, it presented less than $50 \%$ of traditional recipe's salt content, specially sample "2", which presented about $25 \%$ of the traditional recipe's salt content; suggesting that glutamic acid from champignon mushroom was 
able to supply the need of refined salt use during its preparation, when searching for good sensorial acceptance.

It should be noted that edible fungus flavor is highly associated with the presence of substances related to umami's flavor, therefore, it can be used to improve flavors of other ingredients that are present in the culinary preparation (Zhang et al., 2013; Feng et al., 2016). In this study, champignon mushroom demonstrated to carry out this function.

Similarly, Myrdal Miller et al. (2014) and Guinard et al. (2016) concluded that mushroom can be used to reduce salt application on culinary preparations without reducing significantly its acceptance, while improving the preparation's nutritional characteristics.

With regards to chicken stroganoff, it is noted that other ingredients could have cooperated for the good acceptance, especially the chicken and onion, since the first has around $22 \mathrm{mg}$ of glutamic acid in $100 \mathrm{~g}$ of chicken, and the second $51 \mathrm{mg} / 100 \mathrm{~g}$ (Yamaguchi \& Ninomiya, 2000; Nishimura et al., 2016). Therefore, since these ingredients were used in all samples in equivalent quantities, it is understood that they have not been exclusively responsible for the results found.

Evaluating salt perception on all samples it was observed a predominant score indicating balanced perception, tending to intermediary; what coincides with Health Ministry's data, which indicates elevated daily consumption (Sarno et al., 2013).

On the other hand, even with this reduced perception samples were well received over all attributes, indicating the relevance of ingredients naturally rich in glutamic acid application to increase sensorial perception, supplying the need of refined salt (Busch et al., 2013). These data corroborate the proposal of encourage people to share their food with family and friends, widespread by Health Ministry (Brasil, 2014), without loss of flavor responsible for affectivity and food pleasure, and the context in which it is inserted.

\section{Conclusions}

Culinary preparations reduced in sodium when added of ingredients naturally rich in glutamic acid were well approved by judges, regardless of presence or absence of refined salt or aromatic herbs. It is relevant to emphasize that all samples had 50 to $60 \%$ less salt than the traditional version. Accordingly, the use of these ingredients is a good alternative for executing strategies aiming to reduce salt content without reduce sensorial aspect's acceptance.

\section{References}

Amaya-Farfan, J., \& Airoldi, F. P. S. (2011) Presença de glutamato em alimentos. In F. G. R. Reyes (Org.), Umami e Glutamato: aspectos químicos, biológicos e tecnológicos (Cap. 3, pp. 87-110). São Paulo: Plêiade.

Asaria, P., Chisholm, D., Mathers, C., Ezzati, M., \& Beaglehole, R. (2007). Chronic disease prevention: health effects and financial costs of strategies to reduce salt intake and control tobacco use. Lancet, 370(9604), 2044-2053. http://dx.doi.org/10.1016/S01406736(07)61698-5. PMid:18063027.
Brasil. Ministério da Saúde. (2014). Guia alimentar para a população brasileira (2. ed., pp. 156). Brasília: Ministério da Saúde.

Busch, J. L. H. C., Yong, F. Y. S., \& Goh, S. M. (2013). Sodium reduction: optimizing product composition and structure towards increasing saltiness perception. Trends in Food Science \& Technology, 29(1), 21-34. http://dx.doi.org/10.1016/j.tifs.2012.08.005.

Chew, B. L., Fisk, I. D., Fray, R., Tucker, G. A., Bodi, Z., Ferguson, A., Xia, W., \& Seymour, G. B. (2017). The effect of adenosine monophosphate deaminase overexpression on the accumulation of umami-related metabolites in tomatoes. Plant Cell Reports, 36(1), 81-87. http:// dx.doi.org/10.1007/s00299-016-2058-z. PMid:27662835.

Cobiac, L. J., Vos, T., \& Veerman, J. L. (2010). Cost-effectiveness of interventions to reduce dietary salt intake. Heart (British Cardiac Society), 96(23), 1920-1925. http://dx.doi.org/10.1136/hrt.2010.199240. PMid:21041840.

Dermiki, M., Mounayar, R., Suwankanit, C., Scott, J., Kennedy, O. B., Mottram, D. S., Gosney, M. A., Blumenthal, H., \& Methven, L. (2013). Maximising umami taste in meat using natural ingredients: effects on chemistry, sensory perception and hedonic liking in young and old consumers. Journal of the Science of Food and Agriculture, 93(13), 3312-3321. http://dx.doi.org/10.1002/jsfa.6177. PMid:23585029.

Drake, S. L., Carunchia Whetstine, M. E., Drake, M. A., Courtney, P., Fligner, K., Jenkins, J., \& Pruitt, C. (2007). Sources of Umami taste in cheddar and swiss chesses. Journal of Food Science, 72(6), S60-S66. http://dx.doi.org/10.1111/j.1750-3841.2007.00402.x. PMid:17995691.

Dutcosky, S. D. (2013a). Métodos afetivos ou subjetivos: teste quantitativo - escala hedônica. In S. D. Dutcosky. Análise sensorial de alimentos (Cap. 5, pp. 295-355). Curitiba: Champagnat.

Dutcosky, S. D. (2013b). Métodos descritivos: testes de escala. In S. D. Dutcosky. Análise sensorial de alimentos (Cap. 4, pp. 227-295). Curitiba: Champagnat.

Feng, T., Bing, F., Yang, Y., Zhuang, H., Ye, R., Li, X., Xu, Z., \& Wang, K. (2016). Discrimination of edible fungi varieties and evaluation of their umami intensities by using an electronic tongue method. Journal of Food Science and Technology, 192(1), 1393-1400. http:// dx.doi.org/10.1111/ijfs.13096.

Gaitán, D., Chamorro, R., Cediel, G., Lozano, G., \& Gomes, S. (2015). Sodio y enfermedad cardiovascular : contexto en latinoamérica. Archivos Latinoamericanos de Nutricion, 65(8), 206-215.

Galvão, M. T. E. L., Moura, D. B., Barretto, A. C. S., \& Pollonio, M. A. R. (2014). Effects of micronized sodium chloride on the sensory profile and consumer acceptance of turkey ham with reduced sodium content. Food Science and Technology (Campinas), 34(1), 189-194. http://dx.doi.org/10.1590/S0101-20612014005000009.

Ganesan, B., Brown, K., Irish, D. A., Brothersen, C., \& Mcmahon, D. J. (2014). Manufacture and sensory analysis of reduced- and low-sodium cheddar and mozzarella chesses. Journal of Dairy Science, 97(4), 1970-1982. http://dx.doi.org/10.3168/jds.2013-7443. PMid:24485677.

Ghawi, S. K., Rowland, I., \& Methven, L. (2014). Enhancing consumer liking of low salt tomato soup over repeated exposure by herb and spice seasonings. Journal Appetite, 81, 20-29. http://dx.doi. org/10.1016/j.appet.2014.05.029. PMid:24879887.

Guimarães, N. G., Dutra, E. S., Ito, M. K., \& Carvalho, K. M. B. (2010). Adesão a um programa de aconselhamento nutricional para adultos com excesso de peso e comorbidades. Revista de Nutrição, 23(3), 323-333. http://dx.doi.org/10.1590/S1415-52732010000300001.

Guinard, J. X., Myrdal Miller, A., Mills, K., Wong, T., Lee, S. M., Sirimuangmoon, C., Schaefer, S. E., \& Drescher, G. (2016). Consumer acceptance of dishes in which beef has been partially substituted with mushrooms and sodium has been reduced. Appetite, 105, 449459. http://dx.doi.org/10.1016/j.appet.2016.06.018. PMid:27317972. 
Hoppu, U., Hopia, A., Pohjanheimo, T., Rotola-Pukkila, M., Mäkinen, S., Pihlanto, A., \& Sandell, M. (2017). Effect of salt reduction on consumer acceptance and sensory quality of food. Foods, 6(12), 1-12. PMid:29186893.

Kassebaum, N. J., Arora, M., Barber, R. M., Bhutta, Z. A., Brown, J., Carter, A., Casey, D. C., Charlson, F. J., Coates, M. M., Coggeshall, M., Cornaby, L., Dandona, L., Dicker, D. J., Erskine, H. E., Ferrari, A. J., Fitzmaurice, C., Foreman, K., Forouzanfar, M. H., Fullman, N., Gething, P. W., Goldberg, E. M., Graetz, N., Haagsma, J. A., Hay, S. I., Johnson, C. O., Kemmer, L., Khalil, I. A., Kinfu, Y., Kutz, M. J., Kyu, H. H., Leung, J., Liang, X., Lim, S. S., Lozano, R., Mensah, G. A., Mikesell, J., Mokdad, A. H., Mooney, M. D., Naghavi, M., Nguyen, G., Nsoesie, E., Pigott, D. M., Pinho, C., Rankin, Z., Reinig, N., Salomon, J. A., Sandar, L., Smith, A., Sorensen, R. J. D., Stanaway, J., Steiner, C., Teeple, S., Troeger, C., Truelsen, T., VanderZanden, A., Wagner, J. A., Wanga, V., Whiteford, H. A., Zhou, M., Zoeckler, L., Abajobir, A. A., Abate, K. H., Abbafati, C., Abbas, K. M., AbdAllah, F., Abraham, B., Abubakar, I., Abu-Raddad, L. J., Abu-Rmeileh, N. M. E., Achoki, T., Ackerman, I. N., Adebiyi, A. O., Adedeji, I. A., Adsuar, J. C., Afanvi, K. A., Afshin, A., Agardh, E. E., Agarwal, A., Agarwal, S. K., Ahmed, M. B., Kiadaliri, A. A., Ahmadieh, H., Akseer, N., Al-Aly, Z., Alam, K., Alam, N. K. M., Aldhahri, S. F., Alegretti, M. A., Aleman, A. V., Alemu, Z. A., Alexander, L. T., Ali, R., Alkerwi, A., Alla, F., Allebeck, P., Allen, C., Alsharif, U., Altirkawi, K. A., Martin, E. A., Alvis-Guzman, N., Amare, A. T., Amberbir, A., Amegah, A. K., Amini, H., Ammar, W., Amrock, S. M., Anderson, G. M., Anderson, B. O., Antonio, C. A. T., Anwari, P., Ärnlöv, J., Arsenijevic, V. S. A., Artaman, A., Asayesh, H., Asghar, R. J., Avokpaho, E. F. G. A., Awasthi, A., Quintanilla, B. P. A., Azzopardi, P., Bacha, U., Badawi, A., Balakrishnan, K., Banerjee, A., Barac, A., Barker-Collo, S. L., Bärnighausen, T., Barregard, L., Barrero, L. H., Basu, S., Bayou, T. A., Beardsley, J., Bedi, N., Beghi, E., Bell, B., Bell, M. L., Benjet, C., Bennett, D. A., Bensenor, I. M., Berhane, A., Bernabé, E., Betsu, B. D., Beyene, A. S., Bhala, N., Bhansali, A., Bhatt, S., Biadgilign, S., Bienhoff, K., Bikbov, B., Abdulhak, A. A. B., Biryukov, S., Bisanzio, D., Bjertness, E., Blore, J. D., Borschmann, R., Boufous, S., Bourne, R. R. A., Brainin, M., Brazinova, A., Breitborde, N. J. K., Brugha, T. S., Buchbinder, R., Buckle, G. C., Butt, Z. A., Calabria, B., Campos-Nonato, I. R., Campuzano, J. C., Carabin, H., Carapetis, J. R., Cárdenas, R., Carrero, J. J., CastañedaOrjuela, C. A., Rivas, J. C., Catalá-López, F., Cavalleri, F., Chang, J.-C., Chiang, P. P.-C., Chibalabala, M., Chibueze, C. E., Chisumpa, V. H., Choi, J.-Y. J., Choudhury, L., Christensen, H., Ciobanu, L. G., Colistro, V., Colomar, M., Colquhoun, S. M., Cortinovis, M., Crump, J. A., Damasceno, A., Dandona, R., Dargan, P. I., das Neves, J., Davey, G., Davis, A. C., Leo, D. D., Degenhardt, L., Gobbo, L. C. D., Derrett, S., Jarlais, D. C. D., deVeber, G. A., Dharmaratne, S. D., Dhillon, P. K., Ding, E. L., Doyle, K. E., Driscoll, T. R., Duan, L., Dubey, M., Duncan, B. B., Ebrahimi, H., Ellenbogen, R. G., Elyazar, I., Endries, A. Y., Ermakov, S. P., Eshrati, B., Esteghamati, A., Estep, K., Fahimi, S., Farid, T. A., Farinha, C. S. S., Faro, A., Farvid, M. S., Farzadfar, F., Feigin, V. L., Fereshtehnejad, S.-M., Fernandes, J. G., Fernandes, J. C., Fischer, F., Fitchett, J. R. A., Foigt, N., Fowkes, F. G. R., Franklin, R. C., Friedman, J., Frostad, J., Fürst, T., Futran, N. D., Gabbe, B., Gankpé, F. G., Garcia-Basteiro, A. L., Gebrehiwot, T. T., Gebremedhin, A. T., Geleijnse, J. M., Gibney, K. B., Gillum, R. F., Ginawi, I. A. M., Giref, A. Z., Giroud, M., Gishu, M. D., Giussani, G., Godwin, W. W., Gomez-Dantes, H., Gona, P., Goodridge, A., Gopalani, S. V., Gotay, C. C., Goto, A., Gouda, H. N., Gugnani, H., Guo, Y., Gupta, R., Gupta, R., Gupta, V., Gutiérrez, R. A., Hafezi-Nejad, N., Haile, D., Hailu, A. D., Hailu, G. B., Halasa, Y. A., Hamadeh, R. R., Hamidi, S., Hammami, M., Handal, A. J., Hankey, G. J., Harb, H. L., Harikrishnan, S., Haro, J. M., Hassanvand, M. S., Hassen, T. A., Havmoeller, R., Hay, R. J., Hedayati, M. T., Heredia-Pi, I. B., Heydarpour, P., Hoek, H. W., Hoffman, D. J., Horino, M., Horita, N., Hosgood, H. D., Hoy, D. G., Hsairi, M., Huang, H., Huang, J. J.,
Iburg, K. M., Idrisov, B. T., Innos, K., Inoue, M., Jacobsen, K. H., Jauregui, A., Jayatilleke, A. U., Jeemon, P., Jha, V., Jiang, G., Jiang, Y., Jibat, T., Jimenez-Corona, A., Jin, Y., Jonas, J. B., Kabir, Z., Kajungu, D. K., Kalkonde, Y., Kamal, R., Kan, H., Kandel, A., Karch, A., Karema, C. K., Karimkhani, C., Kasaeian, A., Katibeh, M., Kaul, A., Kawakami, N., Kazi, D. S., Keiyoro, P. N., Kemp, A. H., Kengne, A. P., Keren, A., Kesavachandran, C. N., Khader, Y. S., Khan, A. R., Khan, E. A., Khang, Y.-H., Khoja, T. A. M., Khubchandani, J., Kieling, C., Kim, C., Kim, D., Kim, Y. J., Kissoon, N., Kivipelto, M., Knibbs, L. D., Knudsen, A. K., Kokubo, Y., Kolte, D., Kopec, J. A., Koul, P. A., Koyanagi, A., Defo, B. K., Kuchenbecker, R. S., Bicer, B. K., Kuipers, E. J., Kumar, G. A., Kwan, G. F., Lalloo, R., Lallukka, T., Larsson, A., Latif, A. A., Lavados, P. M., Lawrynowicz, A. E. B., Leasher, J. L., Leigh, J., Leung, R., Li, Y., Li, Y., Lipshultz, S. E., Liu, P. Y., Liu, Y., Lloyd, B. K., Logroscino, G., Looker, K. J., Lotufo, P. A., Lucas, R. M., Lunevicius, R., Lyons, R. A., Razek, H. M. A. E., Mahdavi, M., Majdan, M., Majeed, A., Malekzadeh, R., Malta, D. C., Marcenes, W., Martinez-Raga, J., Masiye, F., Mason-Jones, A. J., Matzopoulos, R., Mayosi, B. M., McGrath, J. J., McKee, M., Meaney, P. A., Mehari, A., Melaku, Y. A., Memiah, P., Memish, Z. A., Mendoza, W., Meretoja, A., Meretoja, T. J., Mesfin, Y. M., Mhimbira, F. A., Millear, A., Miller, T. R., Mills, E. J., Mirarefin, M., Mirrakhimov, E. M., Mitchell, P. B., Mock, C. N., Mohammad, K. A., Mohammadi, A., Mohammed, S., Monasta, L., Hernandez, J. C. M., Montico, M., Moradi-Lakeh, M., Mori, R., Mueller, U. O., Mumford, J. E., Murdoch, M. E., Murthy, G. V. S., Nachega, J. B., Naheed, A., Naldi, L., Nangia, V., Newton, J. N., Ng, M., Ngalesoni, F. N., Nguyen, Q. L., Nisar, M. I., Pete, P. M. N., Nolla, J. M., Norheim, O. F., Norman, R. E., Norrving, B., Obermeyer, C. M., Ogbo, F. A., Oh, I.-H., Oladimeji, O., Olivares, P. R., Olusanya, B. O., Olusanya, J. O., Oren, E., Ortiz, A., Ota, E., Oyekale, A. S., Pa, M., Park, E.-K., Parsaeian, M., Patten, S. B., Patton, G. C., Pedro, J. M., Pereira, D. M., Perico, N., Pesudovs, K., Petzold, M., Phillips, M. R., Piel, F. B., Pillay, J. D., Pishgar, F., Plass, D., Polinder, S., Popova, S., Poulton, R. G., Pourmalek, F., Prasad, N. M., Qorbani, M., Rabiee, R. H. S., Radfar, A., Rafay, A., Rahimi, K., Rahimi-Movaghar, V., Rahman, M., Rahman, M. H. U., Rahman, S. U., Rai, D., Rai, R. K., Rajsic, S., Raju, M., Ram, U., Ranganathan, K., Refaat, A. H., Reitsma, M. B., Remuzzi, G., Resnikoff, S., Reynolds, A., Ribeiro, A. L., Ricci, S., Roba, H. S., Rojas-Rueda, D., Ronfani, L., Roshandel, G., Roth, G. A., Roy, A., Sackey, B. B., Sagar, R., Sanabria, J. R., Sanchez-Niño, M. D., Santos, I. S., Santos, J. V., Sarmiento-Suarez, R., Sartorius, B., Satpathy, M., Savic, M., Sawhney, M., Schmidt, M. I., Schneider, I. J. C., Schutte, A. E., Schwebel, D. C., Seedat, S., Sepanlou, S. G., Servan-Mori, E. E., Shahraz, S., Shaikh, M. A., Sharma, R., She, J., Sheikhbahaei, S., Shen, J., Sheth, K. N., Shibuya, K., Shigematsu, M., Shin, M.-J., Shiri, R., Sigfusdottir, I. D., Silva, D. A. S., Silverberg, J. I., Simard, E. P., Singh, A., Singh, J. A., Singh, P. K., Skirbekk, V., Skogen, J. C., Soljak, M., Søreide, K., Sorensen, R. J. D., Sreeramareddy, C. T., Stathopoulou, V., Steel, N., Stein, D. J., Stein, M. B., Steiner, T. J., Stovner, L. J., Stranges, S., Stroumpoulis, K., Sunguya, B. F., Sur, P. J., Swaminathan, S., Sykes, B. L., Szoeke, C. E. I., Tabarés-Seisdedos, R., Tandon, N., Tanne, D., Tavakkoli, M., Taye, B., Taylor, H. R., Ao, B. J. T., Tegegne, T. K., Tekle, D. Y., Terkawi, A. S., Tessema, G. A., Thakur, J. S., Thomson, A. J., Thorne-Lyman, A. L., Thrift, A. G., Thurston, G. D., Tobe-Gai, R., Tonelli, M., Topor-Madry, R., Topouzis, F., Tran, B. X., Truelsen, T., Dimbuene, Z. T., Tsilimbaris, M., Tura, A. K., Tuzcu, E. M., Tyrovolas, S., Ukwaja, K. N., Undurraga, E. A., Uneke, C. J., Uthman, O. A., van Gool, C. H., van Os, J., Vasankari, T., Vasconcelos, A. M. N., Venketasubramanian, N., Violante, F. S., Vlassov, V. V., Vollset, S. E., Wagner, G. R., Wallin, M. T., Wang, L., Weichenthal, S., Weiderpass, E., Weintraub, R. G., Werdecker, A., Westerman, R., Wijeratne, T., Wilkinson, J. D., Williams, H. C., Wiysonge, C. S., Woldeyohannes, S. M., Wolfe, C. D. A., Won, S., Xu, G., Yadav, A. K., Yakob, B., Yan, L. L., Yano, Y., Yaseri, M., Ye, P., Yip, P., Yonemoto, N., Yoon, S.-J., Younis, M. Z., Yu, C., Zaidi, 
Z., Zaki, M. E. S., Zeeb, H., Zodpey, S., Zonies, D., Zuhlke, L. J., Vos, T., Lopez, A. D., \& Murray, C. J. L. (2016). Global, regional, and national disability-adjusted life-years (DALYs) for 315 diseases and injuries and healthy life expectancy (HALE), 1990-2015: a systematic analysis for the Global Burden of Disease Study 2015. Lancet, 388(10053), 1603-1658. http://dx.doi.org/10.1016/S01406736(16)31460-X. PMid:27733283.

Kramer, H. (2017). Kidney disease and the westernization and industrialization of food. American Journal of Kidney Diseases, 70(1), 111-121. http://dx.doi.org/10.1053/j.ajkd.2016.11.012. PMid:28126237.

Kurihara, K. (2015). Umami the fifth basic taste: history of studies on receptor mechanisms and role as food flavor. BioMed Research International, 2015, 1-10. http://dx.doi.org/10.1155/2015/189402. PMid:26247011.

Mattes, M., \& Vickers, Z. (2018). Better-liked foods can produce more satiety. Food Quality and Preference, 64, 94-102. http://dx.doi. org/10.1016/j.foodqual.2017.10.012.

Moreira, S. A. (2010). Alimentação e comensalidade: aspectos históricos e antropológicos. Ciência e Cultura, 62(4), 23-26.

Myrdal Miller, A., Mills, K., Wong, T., Drescher, G., Lee, S. M., Sirimuangmoon, C., Schaefer, S., Langstaff, S., Minor, B., \& Guinard, J. X. (2014). Flavor-enhancing properties of mushrooms in meatbased dishes in which sodium has been reduced and meat has been partially substituted with mushrooms. Journal of Food Science, 79(9), S1795-S1804. http://dx.doi.org/10.1111/1750-3841.12549. PMid:25124478.

Neves, R., Duro, S., Flores, T., Nunes, B., Costa, C., Wendt, A., Wehrmeister, F., \& Tomasi, E. (2017). Atenção oferecida aos idosos portadores de hipertensão: Pesquisa Nacional de Saúde, 2013. Cadernos de Saude Publica, 33(7), e00189915. http://dx.doi.org/10.1590/0102311x00189915. PMid:28792995.

Ninomiya, K. (2015). Science of umami taste: adaptation to gastronomic culture. Flavour (London), 4(13), 1-5. http://dx.doi.org/10.1186/20447248-4-13.

Nishimura, T., Goto, S., Miura, K., Takakura, Y., Egusa, A. S., \& Wakabayashi, H. (2016). Umami compounds enhance the intensity of retronasal sensation of aromas from model chicken soups. Food Chemistry, 196(1), 577-583. http://dx.doi.org/10.1016/j.foodchem.2015.09.036. PMid:26593530.

Oliveira, A. S., Dantas, N. M., \& Pinto-e-Silva, M. E. M. (2018). Consumer acceptance and salty taste intensity of culinary preparations in a food service in the city of São Paulo. Journal of Culinary Science \& Technology, 1-12. http://dx.doi.org/10.1080/15428052.2018.1507857.

Popkin, B. (2015). Nutrition transition and the global diabetes epidemic. Current Diabetes Reports, 15(9), 64. http://dx.doi.org/10.1007/ s11892-015-0631-4. PMid:26209940.

Popkin, B. M., Adair, L. S., \& Ng, S. W. (2012). Global nutrition transition and the pandemic of obesity in developing countries. Nutrition Reviews, 70(1), 3-21. http://dx.doi.org/10.1111/j.17534887.2011.00456.x. PMid:22221213.

Sarno, F., Claro, R. M., Levy, R. B., Bandoni, D. H., \& Monteiro, C. A. (2013). Estimativa de consumo de sódio pela população brasileira, 2008-2009. Revista de Saude Publica, 47(3), 571-578. http://dx.doi. org/10.1590/S0034-8910.2013047004418. PMid:24346570.

Sarno, F., Claro, R. M., Levy, R. B., Bandoni, D. H., Ferreira, S. R. G., \& Monteiro, C. A. (2009). Estimativa de consumo de sódio pela população brasileira, 2002-2003. Revista de Saude Publica, 47(2), 219-225. http://dx.doi.org/10.1590/S0034-89102009005000002. PMid:19225699.

Silveira, C., \& López, R. A. L. (2011). O umami nas culturas antigas. In F. G. R. Reyes (Org.), Umami e glutamato: aspectos químicos, biológicos e tecnológicos (Cap. 1, pp. 29-52). São Paulo: Plêiade.
Siqueira, A. S. E., Siqueira-Filho, A. G., \& Land, M. G. P. (2017). Análise do Impacto econômico das doenças cardiovasculares nos últimos cinco anos no Brasil. Arquivos Brasileiros de Cardiologia, 109(1), 39-46. PMid:28591251.

Sociedade Brasileira de Cardiologia - SBC. (2007). $5^{\circ}$ Diretrizes Brasileiras de Hipertensão Arterial. Arquivos Brasileiros de Cardiologia, 89(3), 24-e79. http://dx.doi.org/10.1590/S0066-782X2007001500012.

Sociedade Brasileira de Cardiologia - SBC. (2016). $7^{\circ}$ Diretriz Brasileira de Hipertensão Arterial. Arquivos Brasileiros de Cardiologia, 107(3), 195-288. http://dx.doi.org/10.5935/abc.20160152.

Souza, A. M., Pereira, R. A., Yokoo, E. M., Levy, R. B., \& Sichieri, R. (2013). Alimentos mais consumidos no Brasil: Inquérito Nacional de Alimentação 2008-2009. Revista de Saude Publica, 47(1, Supl), 190S-199S. http://dx.doi.org/10.1590/S0034-89102013000700005.

Souza, P. L. C., \& Silvestre, M. R. S. (2013). Alimentação, estilo de vida e adesão ao tratamento nutricional no Diabetes Mellitus Tipo 2. Revue de l'Est, 40(4), 541-555.

Stone, H., \& Sidel, J. (2004). The organization and operation of a sensory evaluation program. In H. Stone \& J. Sidel. Sensory evaluation practices (Chap. 2, pp. 23-79). California: Elsevier. http://dx.doi. org/10.1016/B978-012672690-9/50006-8.

Stone, H., Bleibaum, R. N., \& Thomas, H. A. (2012). Affective testing. In H. Stone, R. N. Bleibaum \& J. L. Sidel (Eds.), Sensory evaluation practices (4th ed., pp. 306-309). USA: Elsevier Academic Press. http:// dx.doi.org/10.1016/B978-0-12-382086-0.00007-8.

Trieu, K., Neal, B., Hawkes, C., Dunford, E., Campbell, N., RodriguezFernandez, R., Legetic, B., McLaren, L., Barberio, A., \& Webster, J. (2015). Salt reduction initiatives around the world-A systematic review of progress towards the global target. PLoS One, 10(7), 1-22. http://dx.doi.org/10.1371/journal.pone.0130247. PMid:26201031.

United States Department of Agriculture - USDA. (2015). USDA National Nutrient Database for Standard Reference. Agricultural Research Service, Nutrient Data Laboratory. Retrieved from https:// ndb.nal.usda.gov/ndb/search/list

Universidade Estadual de Campinas - UNICAMP. (2011). Tabela Brasileira de Composição de Alimentos - TACO (4. ed.). Campinas: UNICAMP/NEPA. Retrieved from http://www.unicamp.br/nepa/ taco/tabela.php?ativo=tabela

Wang, G., \& Labarthe, D. (2011). The cost-effectiveness of interventions designed to reduce sodium intake. Journal of Hypertension, 29(9), 1693-1699. http://dx.doi.org/10.1097/HJH.0b013e328349ba18. PMid:21785366.

Webster, J., Trieu, K., Dunford, E., \& Hawkes, C. (2014). Target salt 2025: a global overview of national programs to encourage the food industry to reduce salt in foods. Nutrients, 6(8), 3274-3287. http:// dx.doi.org/10.3390/nu6083274. PMid:25195640.

World Health Organization - WHO. (2006). Reducing salt intake in populations. In World Health Organization - WHO. Report of a WHO Forum and Technical Meeting. Genebra, Suíça: WHO. Retrieved from http://www.who.int/dietphysicalactivity/Salt_Report_VC_april07.pdf

Yamaguchi, S., \& Ninomiya, K. (2000). Umami and food palatability. The Journal of Nutrition, 130(4, Suppl), 921S-926S. http://dx.doi. org/10.1093/jn/130.4.921S. PMid:10736353.

Zanetti, M. L., Arrelias, C. C. A., Franco, R. C., Santos, M. A., Rodrigues, F. F. L., \& Faria, H. T. G. (2015). Adesão às recomendações nutricionais e variáveis sociodemográficas em pacientes com diabetes mellitus. Revista da Escola de Enfermagem da USP, 49(4), 619-625. http:// dx.doi.org/10.1590/S0080-623420150000400012.

Zhang, Y., Venkitasamy, C., Pan, Z., \& Wang, W. (2013). Recent developments on umami ingredients of edible mushrooms - a review. Trends in Food Science \& Technology, 33(2), 78-92. http:// dx.doi.org/10.1016/j.tifs.2013.08.002. 